Bogdan Szlachta ${ }^{\odot}$

\title{
THE CATHOLIC CHURCH IN LIBERAL DEMOCRACY
}

\section{RIGHTS OF A HUMAN PERSON AND HUMAN RIGHTS}

Bogdan Szlachta, Full Professor of Humanities, lawyer and philosopher, Head of the Chair of Political Philosophy at the Jagiellonian University in Krakow and Chair of Theory and Philosophy of Politics at the Academy Ignatianum in Krakow, bogdan.szlachta@uj.edu.pl

The concept of human rights, supposedly of universal importance, is usually derived from the tradition referred to as 'Western'. Although the 'classic approaches' - Greek, Roman and Christian, refer to the norms of natural law, making them the basis or limits of the rights of individuals, in modern approaches the relation is reserved, in the manner that rights become primary to norms. Although liberals of the $17^{\text {th }}$ and $18^{\text {th }}$ centuries consider the law of nature as a tool for their protection, starting from the $19^{\text {th }}$ century, the rights (already called human rights) have been increasingly perceived as positive abilities to articulate own, subjective preferences of individuals. This evolution needs to be accounted for in the studies carried out by representatives of various cultures, since the comprehension of an individual (and even a 'human person' as in contemporary Catholic social teaching) as an essentially culturally unconditioned one, is its ineradicable element.

Keywords:

Catholic social teaching, democracy, law of nature, liberalism, natural law, rights 


\section{GENERAL PROBLEMS}

The position of the Roman Catholic Church as a community of believers, with priests serving in its hierarchical structure as guides to salvation, was shaped in late ancient and medieval monarchies and republics. The process was marked not only by dualistic and monistic doctrines, characteristic of the Latin and Greek world respectively, but also by the formula of Pope Gregory the Great who held his office at the turn of the $6^{\text {th }}$ and $7^{\text {th }}$ century. Based on St. Augustine's philosophy, the formula assumed that rulers and their subjects would slowly but surely transform their conscience and eventually come to the path which leads to salvation. In what Augustine called the earthly cities, people's intentions would be increasingly motivated not by the fear of punishment, but the promise of redemption, thus moving them toward the right end established by God's sacrifice for the sake of mankind marked by the original sin. Gregory's formula has not been forgotten today: the Church still hopes for people of different cultures to understand the message of the sacrifice, so beautifully expounded by St. Paul. Less and less, however, is being said about the natural law that is supposed to set the universal normative boundaries for human actions, perhaps established by God Himself and corresponding to the ideal of humanity conceived by Him before the act, or process of creation. The idea of fixed norms to be recognised by human reason, present in St. Thomas Aquinas, but also in John Paul II's 1993 Encyclical Veritatis Splendor or even in the International Theological Commission's 2009 document In Search of a Universal Ethic: A New Look at the Natural Law, is now being abandoned in favour of human rights founded on the innate dignity of every human person created by God. It is precisely this change, already mentioned by Pope Benedict XVI in his famous 2011 Bundestag speech on the increasingly countercultural nature of the Christian science of law, which is going to be the subject of my paper. I will argue that this change is determined by the context of liberal democracy and might be seen as a reaction of the Catholic Church concerned about the condition of Western societies, where liberal justifications are being used to transgress the boundaries once set by the norms of natural law.

I am not going to analyse the institutional shape of liberal democracy which is wellknown and does not need an in-depth commentary. Suffice it to say that this shape is determined by several basic principles; most importantly, by the legislative representation of the 'collective sovereign' and the separation of powers among a few branches, based on the idea of checks and balances. The mechanism founded by these principles refers to groups of diverse needs and preferences, made up by individuals who are subjects of human and civil rights granted to them by the constitution. Liberal-democratic constitutions speak little of obligations and if they do, the obligations are either interpersonal duties or duties to the state. Instead, what I am interested in here is the problem I shall call normative: the confrontation of liberal-democratic and Catholic understandings of human and civil rights. I disagree both with Carl Schmitt who argued that modernity is founded on the 'optimistic vision of the man' and with Martin Heidegger's thesis (as quoted in Harry Mulisch's novel The Discovery of Heaven) that modernity is 'solipsistic' by nature. I rather 
follow the Jesuit Naphta from Thomas Mann's The Magic Mountain in arguing that its main problem is the foundation of it as a modern subject solely in relation to society, not to any metaphysically superior being. Consequently, the modern man is grounded only in 'this world' and is losing interest in the supernatural end. The ideal of earthly selfrealisation is offered to modern man by liberal democracy which guarantees individuals a set of inviolable rights and liberties. The use of these rights is supposed to make them discover and reveal their unique selves, and their needs and preferences no longer related to the anticipation of salvation but rather to the comfortable coexistence with others. My 'normative problem' does not refer to the democratic moment of liberal democracies; I am not concerned with the disputes on the aggregative, deliberative or agonistic nature of democracy as they all share the individualistic perspective of the common. The problem I am concerned with seems to be deeper: no matter how the 'democratic environment' is conceptualised, we are already used to thinking of rights and liberties of the individual as the only legitimate point of departure since it is the individual who is essentially conceived of as the main actor of this environment.

Two remarks, however, need to be made about today's liberal democracies. First, we shall not forget about the increasing tendency to expose the 'cultural rights' of not only individuals but also groups. These 'cultural groups' are no longer defined solely by religion (although the growing Muslim population in Western countries makes the issue up-todate) but also by, for example, gender identification. If the rights and liberties are attributed to both individuals and groups, the liberal component of democracies is bound to change dramatically. Consequently, the question will come up who is to be protected by the liberaldemocratic state: individuals of the groups they belong to or the groups which will be granted legal autonomy like medieval corporations. Second, the very nature of the liberal component might be problematic. Especially in the agonistic model, liberalism is said to restrict democracy which is the area of an inconclusive struggle to include those who had been excluded and, as such, it cannot respect any permanent, unquestionable points of reference like the catalogue of individual rights and liberties. That said, these problems are of no concern to us as we are moving in another direction: to grab the nature of some more permanent changes, initiated already in the early modern age and ongoing nowadays, with consequences more and more visible to us.

Let us start by saying that the classical approach, inspired mostly by Aristotle and the Stoics, and also used by Roman lawyers, recognised the primacy of the normative order not established by God, but the people. However, the order was not consensually agreed on but rather found in the 'nature of things' or long-term principles. The appeal to nature was at times (vide Aristotle) founded on the argument of 'inborn inclinations' common to all representatives of human kind. Once the inclinations to live, procreate, belong and learn the essence of things were found, they had to be protected by what was later on called the 'norms of natural law', not revealed by God but recognised by inborn, human reason. That way the normative context was also established for legislation: no matter who the lawmakers were, they were supposed to respect the boundaries set by these norms. As long as their legislation was consistent with the norms of natural law, these boundaries were not 
violated and the law-maker was doing the right thing protecting the inborn inclinations of human kind. Human nature was to be realised both by the law-maker and individuals, supposed to follow the norms and thus live in accordance with their own inclinations. All in all, the construction was simple: legal order was good and individual actions were rightful only if and as long as they followed the superior natural law. That also means that legal and moral elements of the construction were identical as they both shared the common foundation of natural human inclinations.

\section{AQUINAS'S IDEA OF LAW AND RIGHTS: LAW BEFORE RIGHTS}

Things got complicated with the coming of the Christians, whose teachings were based not on Aristotle's theses, but on the theses found in the Old Testament. Consequently, their 'superior law' was not derived from the nature of things and personal inclinations but came from the outside, revealed by the commanding of God. In the late middle ages, Christian philosophers tried to reconcile the teachings of the Bible with classical thought, the project which culminated in St. Thomas Aquinas, whose theses were later adopted by many Aristotelians. As argued by Thomas (with clear references to Stoicism), divine law was not directly revealed to humans but rather naturally 'inscribed' in their 'hearts'. Unlike the pre-Christian conceptions of natural law, however, the late medieval ones had to consider the distinction into legal and moral normative orders introduced by the dualistic doctrines of the early middle ages: while the legal order is compelling by nature, the function of the moral order is to guide humans toward salvation. When Aquinas is discussing man's final end, he starts with the Aristotelian conception of 'happiness' and ends with the Christian doctrine of the beatific vision of God in heaven. When he is discussing virtues, he completes his treatment of them by talking about the 'theological virtues' of faith, hope and charity. But we also know that Aquinas believed in the harmonious relation between all truths, however attained, and he wished to exhibit and illustrate this harmony. First of all, he maintains that in every human act the will is directed towards an end, towards something apprehended as or thought to be good, that is, something which is known or thought to be perfect in some way as the subject who desires and chooses. And in accordance with his finalistic conception of nature, Aquinas goes on to argue that human will is necessarily set towards the final or ultimate good of man as such, and that it is under the impulse of this dynamic and innate will's orientation that we make our particular choices, which are secondary to the main choice very much like all particular ends are secondary to the ultimate or final end. But it must be remembered that Aquinas presupposes the existence of God, who created things with innate tendencies towards the development of their own real potentialities. He presupposes that human nature has been created by a personal God who would have not created it with an unavoidable impulse towards a non-existent good or an unobtainable good and - as a consequence - that all human beings, like all created things, tend towards the actualisation of the potentialities of their natures, even though they may never use terms like 'supreme' or 'final good'. However, they do so not only instinctively 
but also by means of intellect and will. Natural intellect alone is capable to see the idea of human good. For Aquinas, grace does not annul but perfects human nature: revelation sheds further light, but it does not cancel the truths attainable by purely philosophical reflection.

Although the differences between Aristotle's and Aquinas's conceptions of man's ultimate good may be great, it is clear that both men developed finalistic or teleological theories of ethics. For both, human acts derive their moral quality from their relation to man's final end. According to Aquinas, every human act has two sides, interior and exterior, 'formal' and 'material'; the absence of any of them, especially of the right intention which belongs to the interior act, is sufficient to prevent our calling it good in an unqualified manner. In order for a human act in the full sense to be morally good, it must be compatible both 'formally' and 'materially' with the attainment of the final end. What is done, as well as the intention with which the act is performed and the way in which it is performed, must be compatible with the attainment of the final end. From this relation the act ultimately derives its moral quality.

In connection with Aquinas's idea of the law, we may say that the natural reason of all men sees that some acts are necessary to obtain man's good; for example, this natural reason sees that it is necessary to take reasonable means to preserve one's life. Law in general, as he says, is a rule or measure of human acts, conceived by reason and promulgated with a view to the common good or an ordinance of reason made for the common good by him who has charge of the community, and promulgated, ${ }^{1}$ in virtue of which one is led to perform certain actions and restrained from the performance of others by reason as the first principle of human action, which directs action to its appropriate end. Authority of law is grounded on the will if it is regulated by 'reason when it commands'; this does not mean that for Aquinas the law depends on God's or a lawgiver's arbitrary choice, as it does later, for example, for Scotists. ${ }^{2}$ He speaks of God as an artist who has an idea of the work to

St. Thomas Aquinas, Summa Theologiae 1a 2ae, 90.4, ed. by Thomas Gilby (London, 1966).

The famous members of the Franciscan order, not Dominican as Aquinas, Duns Scotus and William of Ockham, connected the law of nature or God with legal rights. For Scotus ius naturale was not simply neutral with regard to dominium, as was in Aquinas, but it positively ruled it out, since common use was the optimum strategy for men in a state of innocence. For him, common use was the common dominium. It was not the case that the human race collectively had the kind of right over the world, rather that each human being was simply able to take what he needed, and had no right to exclude others from what was necessary for them (Richard Tuck, Natural Rights Theories. Their Origin and Development [Cambridge: Cambridge University Press, 1979], 21-22). John Duns Scotus took dominium to be necessarily private, something which could not only be exchanged, but also defended against the claims of the needy, and quite possibly by violence. Man could have property, which was not purely a feature of a social life. In Ockham's case, one may see identification of the right of use and the right of ownership and, as a consequence, identification of individual or subjective powers with rights, rights of God or humankind as well as rights of an individual person. In this conception there is no impersonal common good and public norms that may seem to have objective validity. There are public norms which are conventional constructions of these various subjects and which regulate only external relations between citizens. Hence political thought and action is totally concerned with the conflict, balancing and delegating various but always subjective powers-rights. The right of use (ius utendi) was defined by Ockham as a licit power of using an external object, the unwarranted denial of which can be prosecuted in a court 
be created or done and of the means to its fulfilment. God conceives eternally all creatures according to their different kinds: He conceives their ends and the means to the attainment of these ends. Divine wisdom, considered as moving all things according to their several ends in subordination to the end of the whole created universe, the communication of the divine perfection, is the eternal law. Hence the eternal law is nothing else than the plan of the divine wisdom considered as directing all the acts and motions' of creatures ${ }^{3}$ to the attainment of their ends. Man, as a rational and free being, is capable of acting in ways which are incompatible with this law and it is therefore essential that he should know the eternal law so far as it concerns himself. Although man cannot read off the eternal law in God's mind, he can discern the fundamental tendencies and needs of his nature, and by reflecting on them he can come to a knowledge of the natural moral law. Every man

of law; as to the right of ownership: a principal power of laying claim to a thing in court and of using it in any way not prohibited by natural law; both in: Opus Nonaginta Dierum, ed. by R F Bennett and J G Sikes, ch. 2 (Manchester: Manchester University Press, 1940), 304, 310. See also Arthur Stephen McGrade, 'Ockham and the Birth of Individual Rights', in Authority and Power. Studies in Medieval Law and Government presented to Walter Ullmann on his Seventieth Birthday, ed. by Brian Tierney and Patrick Linehan (Cambridge: Cambridge University Press, 1980), 149-151. See also Michel Villey, 'La Genèse du droit subjectif chez Guillaume d'Occam', Archives de Philosophie du Droit 9 (1964), 97-127; Heinrich Rommen, Die ewige Wiederkehr des Naturrechts (München: J. Kösel, 1947), 60; Frederick Copleston, A History of Philosophy. Ockham to Suarez (New York: Doubleday, vol. III, 1953), 51; Arthur Stephen McGrade, The Political Thought of William of Ockham. Personal and Institutional Principles (Cambridge: Cambridge University Press, 1974). But see also Brian Tierney, Religion, Law, and the Growth of Constitutional Thought. 1150-1650 (Cambridge: Cambridge University Press, 1982); John N Figgis, Studies of Political Thought from Gerson to Grotius. 1414-1625 (Cambridge: Cambridge University Press, 1931); Tuck, Natural Rights Theories; Bogdan Szlachta, 'Nowożytny przełom w pojmowaniu prawa naturalnego', in Kształtowanie postawy obywatelskiej, ed. by P. Lenartowicz (Kraków: Wydawnictwo WAM, 1997), 35-80. Scotists' nominalism meant a crisis in Scholastic method, a quarrel about 'universals' and an anticipation of the modern theory of powers-rights. The vindication of the will's primacy over the intellect led to the denial that ethical values can have any other foundation but the will of God that imposes them. The notion of God as an unlimited and arbitrary power implied the reduction of all moral laws to inscrutable manifestations of divine omnipotence. The basis of the 'natural system of ethics' was discarded. Natural law ceases to be a bridge between God and man. It affords no indication of the existence of an eternal and immutable order. It no longer constitutes the measure of man's dignity and of his capacity for participation in that order, a standard of good and evil available to all rational creatures, because for nominalists an action was not good thanks to its suitability with the essential nature of man but thanks to God's arbitral will. Validity of the norms was founded not on the standards of God's reason as well as man's reason but only on God's absolute will. Law was not reason but will, pure will without any foundation in reality, without foundation in the essential nature of things. It is as if the notion of sovereignty was applied here to the divine law-giver himself. The notion of sovereignty of God as legibus solutus became the pivot of Calvin's ethics and theology and later the foundation of the modern conception of sovereignty as well as the new conception of natural law which was the product of the Age of Reason. But this influence was somehow paradoxical because the revival of natural law which took place at the turn of the 16th and 17th century was essentially a rejection of the nominalist or voluntarist theory of law. Thus Grotius's famous proposition that natural law would retain its validity even if God did not exist, which appears as a turning point in the history of Western thought, was the answer to the challenge not of rational-realistic ethics of Aquinas, but of voluntarist and nominalist ones. It meant the assertion that command is not the essence of law and that natural law is independent of God's will. This meaning goes in the same direction as a convenient summary of Catholic conception which was given at the beginning of the 17th century by Spanish Jesuit Francisco Suárez, who also took the view that natural law does not depend on the will 'of any superior', especially the will of the absolute monarch.

Aquinas, Summa Theologiae, 1a 2ae, 93.1. 
possesses the natural inclinations to the development of his possibilities and the attainment of the good for man. Every man also possesses the light of reason whereby he can reflect on these fundamental inclinations of his nature and promulgate to himself the natural law, which is the totality of the universal precepts or dictates of right reason concerning the good which is to be followed and the evil which is to be shunned. By the light of his own natural reason, therefore, man can arrive at some knowledge of natural law. Since this law is a participation in or reflection of eternal law and so far as the reflection concerns human beings and their free acts, man is not left in ignorance of eternal law which is the ultimate rule of all conduct. ${ }^{4}$

For Aquinas, therefore, it is human reason which is the proximate or immediate promulgator of natural law. This law is not without a relation to something above itself; for it is, as we have seen, the reflection or participation in eternal law. Inasmuch as it is immediately promulgated by human reason, we can speak of a certain autonomy of practical reason. This does not mean that man can alter the natural law which is founded in his nature. But it means that the human being does not receive the law simply by imposition from above: he recognises or can recognise its inherent rationality and binding force, and he promulgates it to himself. ${ }^{5}$ In Aquinas's conception of natural law as the expression of man's dignity and power, man is the only being created to participate intellectually and actively in the rational order of the universe. Man is called to do so because of his rational nature. It is the light of natural reason which enables us to discern good from evil. St. Thomas's notion of the light of reason is of great importance. Man is conceived to hold the unique position of being at the same time a subject of God and His co-operator. However, man participates in two worlds. The order of the precepts of natural law corresponds to the order of his natural inclination, includes the qualities which he has in common with all created beings as well as those which are distinctive of his own rational nature. What he has in common with all created things is the desire for self-preservation. Hence the first group of the precepts of natural law comprises all that makes for the preservation of human life. But man also has similarities with animated beings with a further inclination to more specific ends. Consequently, it is right to say that 'what nature has taught all animals' pertains to natural law - such as sexual relationships, the rearing of offspring and the like. Finally, there is in man a certain inclination to know the truth about God and to live in society. All those actions pertain to

4 The natural law is nothing else but a participation of the eternal law in a rational creature (Aquinas, Summa Theologiae, 1a 2ae, 91.2).

5 It is clear - says Aquinas - that the whole community of the universe is governed by divine reason, by eternal law; all things are subject to divine Providence and are measured and regulated by this kind of rational law; all participate to some degree in it, in so far as they derive from it certain inclinations to those actions and aims which are proper to them. But, of all others, rational creatures are subject to divine Providence in a very special way; being themselves participators in Providence itself, in that they control their own actions and the actions of others. So they have a certain share in divine reason itself, deriving therefrom a natural inclination to such actions and ends as are fitting. This participation in eternal law by rational creatures is called natural law; natural law which is nothing else than the impression of the divine light in us and participation of eternal law in rational creatures (Aquinas, Summa Theologiae, 1a 2ae, 91.1, 2). 
natural law to which man has a natural inclination: and among such it is proper to man to seek to act according to reason, which gives first principles of rightness for everybody and is equally known by every one or the same for all as a norm of right conduct and is equally well known by everyone. ${ }^{6}$

The order of the precepts of natural law follows the order of natural inclinations; and - as a consequence - these precepts as well as these inclinations or tendencies are directing man towards his ultimate good, giving him knowledge of what is necessary for the right ordering of his life and also the conviction that he should live in society with other men. Aquinas thought of man as tending naturally and inevitably towards his perfection, towards the actualisation of his potentialities as man, towards his final end or good. And he thought of man's reason as discerning the acts necessary for the attainment of this end and ordering them while forbidding their contraries. In this sense, obligation or norm is imposed by practical reason, binding the free will to perform the necessary acts to attain the final end or man's good and to abstain from acts which are incompatible with its attainment. But, at the same time, for Aquinas, one may act and one has iura only on the foundation of natural law and in the area which presents its objective norms. In his doctrine, we have no modern natural rights theory although we have natural law theory. Something can be said to be according to the ius naturale in two ways, said Aquinas when he spoke about man's natural life. One, if nature inclines us to it: such as not to harm another human being. The other, if nature does not prescribe the opposite: so that we can say a man is naked under the ius naturale, since he received no clothes from nature but invented them himself. In this way 'the common possession of all things, and the equal liberty of all is said to be according to the ius naturale: for distinctions between possessions and slavery were not the products of nature but were made by human reason for the advantage of human life.' In the state of nature, men have no rights, because the ius naturale is neutral in the areas of personal servitude and private property. In spite of all modern natural rights theory, there are no prima facie rights to men; men do not have a prima facie natural right to absolute liberty any more than they have a prima facie natural right to dominate other men. ${ }^{8}$

Aquinas generally used ius and lex - right and law - as interchangeable terms, pointing that legalism should follow the grain of reality and that continuity between implanted right and enacted law should be kept. Whereas medieval jurists generally spoke of ius naturale

$6 \quad$ Ibid. 94.2. Like the ancient Roman lawyer Ulpian, Aquinas pointed out that man has something in common with all created beings, with plants and animals for example; like all medieval Christian lawyers, he also pointed out that man has something in common with a supernatural Being (God) or beings like angels but not only with Him or them. As to the relation between negative borders of freedom of human legislation Aquinas said that the validity of law depends upon its justice. But in human affairs a thing is said to be just when it accords aright with the rule of reason: and, as we have already seen, the first rule of reason is natural law. Thus all humanly enacted laws are in accord with reason to the extent that they derive from natural law. And if a human law is at variance in any particular with natural law, it is no longer legal, but rather a corruption of law (Aquinas, Summa Theologiae, 1a 2ae, 95.2).

Ibid. 94.5.

See Tuck, Natural Rights Theories, 20. 
and theologians of lex naturalis, he was inclined to reverse the usage, preferring lex in his judicial treatise and ius in his theological treatise on the cardinal virtue of justice. Lex was not ius precisely, but in some manner it was its rational expression, because ius signified an objective quality. ${ }^{9}$ If legislation was a part of the practical wisdom of governing the community, one man could rightfully control another only by showing a reason for his power: even omnipotence cannot break the order of truth, but the true and rational legislator ought to have prudentia regnativa, a type of prudence, the intellectual and moral virtue. ${ }^{10}$ A legislator's recta ratio is not so closely linked with ius naturale in Aquinas's doctrine as some contemporary commentators suppose and therefore there is no contrast between ius naturale and lex naturalis. ${ }^{11}$

For St. Thomas, lex means much more than a positive statement and very much more indeed than written law; he often speaks of ius positivum instead of lex positiva, of lex naturalis instead of ius naturale, and - as Brown has supposed - he uses ius and lex metonymously in respect of all of the following kinds of ius-lex: divine, natural, positive and human. ${ }^{12} \mathrm{He}$ does indeed draw a distinction between these terms, but in both of them he presents the same rational substance. Only those iura and leges are valid which are rational - however, not as man's rationality but as the rationality of God and His order. On the other hand, the iura are only valid if they have a legal foundation. It is an important thesis because the substance of personal rights is connected not with personal power or dominium but with rational action which directs man to his ultimate end. We have already seen, however, that for Aquinas, a Christian theologian, man has a supernatural final end or supreme good, the attainment of which transcends his natural power and directs his natural rights through his natural inclinations as well as through the norms of natural law. ${ }^{13}$

9 See, first of all, Aquinas, Summa Theologiae, 1a 2ae, 105.2 ad. 3, 2a 2ae, 57.1 ad 1, 2.

10 See Thomas Gilby, Principality and Polity. Aquinas and the Rise of State Theory in the West (London: Longmans, Green, 1958), 125-128.

11 See Vernon J Bourke, 'Is Thomas Aquinas a Natural Law Ethicist?', The Monist 58. (1974), 62-63.

12 Oscar J Brown, Natural Rectitude and Divine Law in Aquinas. An Approach to an Integral Interpretation of the Thomistic Doctrine of Law (Toronto: Pontifical Institute of Mediaeval Studies, 1981), Appendix I: 'Ius' and 'Lex' in Aquinas (p. 174).

13 In the Catechism of the Catholic Church (n. 36) from 1992 we read: 'The Church, holds and teaches that God, the first principle and last end of all things, can be known with certainty from the created world by the natural light of human reason' (with references not only to Vatican Council I, Dei Filius 2, but also to Vatican Council II, Dei Verbum 6). Without this capacity, man would not be able to welcome God's revelation. Man has this capacity because he is created 'in the image of God' (Gen 1:27). But at the same time, as we read in the next canon (ibid. n. 37), in the historical conditions in which he finds himself [...] man experiences many difficulties in coming to know God by the light of reason alone: Though human reason is, strictly speaking, truly capable by its own natural power and light of attaining to a true and certain knowledge of the one personal God, who watches over and controls the world by his providence, and of the natural law written in our hearts by the Creator; yet there are many obstacles which prevent reason from the effective and fruitful use of this inborn faculty. For the truths that concern the relations between God and man wholly transcend the visible order of things, and, if they are translated into human action and influence it, they call for self-surrender and abnegation. The human mind, in its turn, is hampered in the attaining of such truths, not only by the impact of the senses and the imagination, but also by disordered appetites which are the consequences of original sin. So it happens that men in such matters 
The identification of man's good with 'happiness' or with self-perfection may easily give the impression that Aquinas's ideal was purely individualistic and even egoistic in an unpleasant sense. Yet he regarded life in society as being prescribed by natural law. That is to say, he recognised a natural tendency of human beings to live in society with his fellows, not only in a smaller group of the immediate family circle but also in those larger groups which (in their developed form) are called states or political communities. Social life is thus founded on human nature itself, and both families and states are natural communities. Reason, reflecting on man's fundamental inclinations, says that these societies ought to be formed inasmuch as they are necessary for the development of man's potentialities. It is natural for man to be a social and a political animal, living in community; and this is more true of him than of any other animal, a fact which is shown by his natural necessities, ${ }^{14}$ meaning bodily as well as spiritual needs. Society is therefore not a purely artificial construction but a natural institution as a result of man being what he is. And as founded on human nature, it is willed by God, who created man. This does not mean, of course, that the historical divisions into nations and states are dictated by God but that there should be a civil or political society or societies willed by God, as is shown by the fact that He created man who cannot attain his full stature without society. ${ }^{15}$

Furthermore, every society requires direction and government. For Aquinas it is a mistake to think, unlike both St. Augustine and Locke, that government exists simply in order to keep peace and punish evildoers. According to him, government would be required even if there were no evildoers and even if no one was inclined to disturb the peace. St. Augustine was inclined to say that the state was a result of man's Fall and political authority existed primarily because fallen human beings needed coercive power to restrain their evil tendencies and to punish crime. Locke spoke of anti-rational passions which incline men to break the law of nature. But these were not at all Aquinas's opinions. Man is by nature a social animal. Hence in the state of innocence (if there had been no Fall) men would have lived in society. But a common social life of many individuals could not exist unless there were someone in control to attend to the common good. ${ }^{16}$ Government, like society, is natural and willed by God. It exists primarily to care for the common good, because for the good life of the community three things are required. Firstly, that the community should be established in the unity of peace. Secondly, that the community, united in the bond of peace, should be directed to good action [...]. Thirdly, that through the ruler's diligence there should be a sufficient supply of the necessities for a good life. ${ }^{17}$ The government therefore exists to preserve internal peace and to take care of the community, to promote the moral

easily persuade themselves that what they would not like to be true is false or at least doubtful (with reference to the Encyclical Humani generis by the Roman Pope Pius XII).

14 St. Thomas Aquinas, On the Government of Rulers. De regimine principium, transl. by James M Blythe (Philadelphia: University of Pennsylvania Press, 1997), 1,1.

5 See Frederick Copleston, Aquinas (Harmondsworth: Penguin Books, 1955), 227-229.

Aquinas, Summa Theologiae, 1a 2ae, 96.4.

7 Aquinas, De regimine principium, 1.15. 
well-being of citizens, so far as this can be done by legislation supported by sanctions, and to provide citizens with a sufficient supply of material necessities. In Aquinas's doctrine, there is no place for a contract which constitutes society or government.

\section{NEW (MODERN, ABOVE ALL LIBERAL) PROPOSITIONS: RIGHTS BEFORE LAW}

Since the function of the state as well as the function of its legislator or legislators is to promote the common good which has no individualistic substance, the criterion of good and bad in legislation is its relation, discerned by reason, to common good and not to the interests of individuals or groups. It does not imply that every precept and prohibition of natural law should be embodied in legislation, as will be thought for example by English Puritans. But the state is not entitled to pass legislation which runs counter to natural law in any case. Every human law has the nature of law in so far as it is derived from the law of nature. If in any case it is incompatible with the natural law, it will not be law, but a perversion of law. ${ }^{18}$ And, therefore, Aquinas may say also that the will of the prince has the power of law only when it is rational and directed towards the well-being of the whole community as a perfect whole, ${ }^{19}$ while in any other sense the will of the prince becomes an evil rather than law. ${ }^{20}$

From this view of the relation of human positive law to natural law it naturally follows that just laws are binding while unjust laws are not binding in conscience. A law is unjust, says Aquinas, if it imposes burdens on the citizens not for the common good but to satisfy the cupidity or the ambition of the legislator; if in enacting the law the legislator goes beyond the powers committed to him; or if burdens are imposed in an unfair and disproportionate manner. Laws of this kind are acts of violence rather than laws [...] they do not bind in conscience unless observance of them is required in order to avoid scandal or public disturbance. Laws can also be unjust by contravening divine positive law, namely the precepts of the Decalogue, and laws of this sort ought not to be obeyed. ${ }^{21}$ The sovereignty of the ruler or legislator does not cancel the notion of legal obligation. Positive law does not exhaust the whole range of legal experience. There may be laws other than the commands of the sovereign, laws with a different structure yet nevertheless binding and formally perfect. Natural law and the laws of the international community (ius gentium) are devoid of sanctions but both are properly called laws and are binding even for the sovereign. Like Albericus Gentilis, one of the founders of modern international law, Aquinas may say that

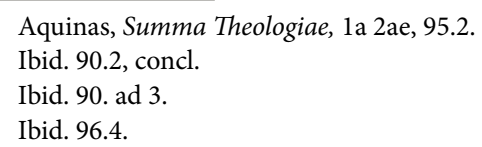


the 'absolute' prince is a prince who is above positive law but under natural law and under the law of nations. ${ }^{22}$

After St. Thomas, the compelling law was being increasingly associated with state legislation and moral law with religious teachings. As a consequence, we find early modern Christianity marked by two alternative understandings of the superior divine law: either the law of juridical importance (in Puritanism, Presbyterianism and some other Calvinist denominations) or moral law (in Catholicism). The tensions in $16^{\text {th }}$ century Europe, greatly inspired by nominalism and voluntarism, involved the essential reformulation of the functions of law, usually ascribed to Hugo Grotius. According to his new formula, so perceptively diagnosed by the Jesuit Naphta, universal human reason continued to be the source of fixed natural norms but the horizon of their application was no longer supernatural; instead of salvation, the law should rather be concerned with the conditions of social peace. Further on, the French 'politicians' went on to conceptualise the legislators solely focused on peaceful, interpersonal coexistence, just like in Augustine's 'earthly cities'. Finally, Jean Bodin emphasised the role of the commanding monarch whose power was to determine the conditions of peace and enforce their observance. ${ }^{23}$

However, although commonly labelled as a founder of absolutism, Bodin (following the 'politicians') did not justify the unconditional primacy of the law-maker. Instead, the choice of religion and 'family property' were those elements which had to be respected by all law-makers, thus setting boundaries to their legislation. To impose the monarch's own religion on others and put arbitrary restrictions on their properties was no longer allowed. That way, let us remark, the limits of legislation were again defined with reference to earthly communities only. At the same time, freedom of religion allowed for alternative visions of salvation: while some Christians favoured the pathway marked by the law of revelation, others respected the limits set by natural law. Even more importantly, there was no agreement on the relation of natural individual rights to divine law: some derived them from the law-making act of God, others preferred to deduce them from universal human nature. Except for early modern republicanism, the split within Western Christianity brought about not only the dispute of Protestants with the Catholic schools of Salamanca and Coimbra but also the philosophy of Thomas Hobbes, equally critical of Catholics, Puritans, common law and the 'divine right of kings' theory. Hobbes rejected the contexts of religion and property, and advocated the theory of the state of nature with individuals led by a self-preservation instinct and holding inborn rights; not to the pursuit of salvation or social peace but to all self-preserving actions. Hobbes's project was revolutionary in postulating the existence of natural egoistic rights whose only aim was to preserve a living body, with no normative boundaries preventing the individual from

22 Albericus Gentilis, Regales Disputationes Tres, 1605 (Disp. I, De Potestate Regia Absoluta, 17). For further information see Alessandro Passerin d'Entrèves, Natural Law. An Introduction to Legal Philosophy (London: Hutchinson University Library, 1957), 67-68.

23 See above all Arthur P Monahan, From Personal Duties towards Personal Rights. Late Medieval and Early Modern Political Thought, 1300-1600 (Montreal-Kingston: McGill-Queen's University Press, 1994). 
hurting others. No 'superior law' was to be respected either by the individual or legislator ('state' or 'Leviathan') whose function was to establish fundamental norms of the law of nature, thereby restricting rights of individuals in exchange for protecting their bodies and peaceful coexistence.

What is interesting here, however, is not so much the limitation of rights by the 'state' but the absence of moral duties. By negating 'positive political theology' and God's interference in the world of politics, Hobbes both disregarded any supreme law in formulating norms of the law of nature and made all moral issues secondary to legal resolutions. Consequently, no morality, either divine or natural, could any longer justify the disobedience to the legislator called 'state'. Even individuals were only allowed to execute their inborn rights if they did not violate the norms established to keep peaceful coexistence; in other words, individuals might not seek peace but had to respect its conditions. When Hobbes denied the autonomy of the Church and identified state sovereignty with supreme moral jurisdiction, he was not far away from Erastianism with its recognition of 'state' as the only source of the Church's legislative, judicial and sacramental rights. Hobbes made the political order self-centred, focused solely on making and keeping peace between individuals, on public safety and order. The problem he faced was how to personally represent the impersonal state which is similar to 'person': ${ }^{24}$ when its assumed unity proved elusive and many actors (also religious) claimed the right to representation, and vicious power struggles began. The thing is that neither their participants, nor Hobbes's followers respected any 'supreme law’. Admittedly, to restrict legislative freedom, John Locke went on to present a catalogue of inviolable inborn rights to be protected by the norm of the law of nature not derived from the 'state' but from human reason. But even this project emphasised agreement as the only conception of civil society with its principles and, as such, it disregarded the role of universal religious morality. Equally critical of atheists and 'papists', Locke basically echoed Hobbes in his concern with the conditions of peace between individuals and nothing more. Unlike classical projects or even the project of the Salamanca School, his norm of the law of nature was to protect inborn rights, not inclinations. It was these rights, further on transformed into human rights, which were supposed to allow individuals the unrestrained articulation of their needs and preferences. They defined the 'juridical boundaries' of a subject's freedom which could be violated by no law-maker - the institutions of civil society included.

The modern theory of the law of nature is, properly speaking, first of all a theory of rights which are restricted or guaranteed by norms or a norm named the law of nature. A momentous change has taken place under the cover of the same verbal expressions.

${ }_{24}$ The Hobbesian commonwealth, said David Runciman, is an association of individuals who have all agreed to abide by certain rules. It is an association which has no substantive end of its own, beyond the end which its members share as individuals and which conditions the terms of their original agreement - 'namely, the Peace of the Subjects within themselves, and their Defence against a common Enemy' (Thomas Hobbes, Leviathan [London: Dent, 1931], 150). 'Peace is secured through the rule of law [...]. Hobbes's civil association is a person' (David Runciman, Pluralism and the Personality of the State [Cambridge: Cambridge University Press, 1997], 15-16). 
The ius naturale of the modern political philosopher is no longer either lex naturalis of the medieval moralist or ius naturale of the Roman lawyer. These different conceptions have only the name in common. This significant fact was pointed out by Hobbes: though they speak of this subject use to confound ius and lex, right and law: yet they ought to be distinguished; because right consisteth in liberty to do, or to forbear: whereas law determineth, and bindeth to one of them: so that law and right differ as much, as obligation and liberty. ${ }^{25}$ Following this distinction, he argued that civil war is caused by each individual claiming the right to judge the law in accordance with their subjective standard of conscience or 'private judgement'. ${ }^{26}$

The different meanings of the word ius were for a long time known to the lawyers who had been brought up in the study of Roman law. They carefully distinguished between 'objective' and 'subjective right', between the norma agendi (the rule of action) and the facultas agendi (the right to act) which can both be indicated by the same name of ius. But they never overlooked the fact, which Hobbes seems either to ignore or to implicitly deny, that the two meanings of ius are not antithetical but correlative. In the language of the law schools and as we have seen with St. Thomas, ius could be used in an 'objective' as well as in a 'subjective' sense: but the latter always presupposes the former. There is a facultas agendi inasmuch as there is a norma agendi. There is a 'right' inasmuch as there is a law. But for the great majority of modern law nature writers, Hobbes's anarchical conception of natural right as opposed to natural law was crucial. ${ }^{27}$ Even Locke in the Two Treatises of Government argued that in a system of popular sovereignty, members would withdraw their consent and revolt whenever a law would conflict with their private interest, claiming that it would contravene the public good. Although he said that the freedom of an Englishman consists in his liberty to dispose of his actions and possessions according to the laws of England, his emphasis was shifting more and more from the objective to the subjective meaning of ius. For him individual human freedom was connected not with the ultimate end or good of man, nor with the norms of natural law which obliges all men, but with the right of the individual who has the power quite similar to that which nominalists and voluntarists had given to God alone. In his doctrine on individuals, very similar to the Byzantine prince,

Hobbes, Leviathan, I.14.

26 Ibid. II.29. Leo Strauss said in his famous lectures: We can overcome this danger only by considering the fact that for every conscientious scholar the problem of natural right is not a partisan affair. At a superficial glance, the issue of natural right presents itself today as a matter of party allegiance. Looking around us we see two hostile camps, heavily fortified and strictly guarded. One is occupied by the liberals of various descriptions - to use this somewhat loose term; the other by the Catholic and non-Catholic disciples of Thomas Aquinas. But both armies, and in addition those who prefer to sit on the fence or to hide their heads in the sand, are, if I may heap metaphor on metaphor, in the same boat. They are all modern men. No matter how neutral we may be, we are all in the grip of the same dilemma (Leo Strauss, Six lectures 1949, 7). See also Ernst Levy, 'Natural Law in Roman Thought', Studia et Documenta Historiae et Iuris 15, (1949), 7; John Walter Jones, Historical Introduction to the Theory of Law (Oxford: Clarendon Press, 1940), 100-108.

27 See positions by d'Entrèves, Natural Law, 59-60 (for the majority of these writers 'natural law was the necessary presupposition of natural right', 60) and the opposite view by Leo Strauss, The Political Philosophy of Hobbes (New York: The University of Chicago Press, 1936), 156. 
were the living embodiments of law (lex animata) and their will and law became correlative notions. In his natural right theories, one may see once again the old idea of Roman and glossators' texts of a supreme and ultimate human power from which all laws proceed; the idea which undermines all possibility of serious natural law thinking because natural law is not a proper law if sovereignty is the essential condition of legal experience, as it is not possible to conceive of a law of nature when command is the essence of law. ${ }^{28}$

If a rule may be laid down as a command, we cannot distinguish the 'compelling' and the 'directing' aspects of law (vis coactiva vs vis directiva). Hence, while for Aquinas the 'directing' aspect of law was crucial because it was the element of justice, for Locke both aspects are identified. He said not only that political power is a right of making laws, ${ }^{29}$ but also that the state of nature, the pre-political state, has a law of nature to govern it, which obliges every one, supposing the law of nature as a norm or set of norms has no political character if only political power is a right of making this norm or these norms. Locke said at the same time that reason, which is that law (of nature), reaches all mankind who will but consult it, that, being all equal and independent, no one ought to harm another in his life, health, liberty, or possessions. ${ }^{30}$

In this context we must ask a question about the primary rights as a capacity of the individual who realises his personal ability or power over law as a set of norms which rules the actions of individuals. And a second question: what is a substantial relationship between norm of the law of nature and such individual ability or power? Locke writes, on the one hand, that all men may be restrained from invading others' rights, and from doing hurt to one another ${ }^{31}$ because rights of every man create a property in his own person. ${ }^{32}$ And, on the other hand, that the law of nature willeth the peace and preservation of all mankind. ${ }^{33}$ In these words he creates a very important doctrine for all liberal tradition and modern natural law thinkers on the priority of rights before law. Now, law as the set of norms, identified with human reason, has no objective context and is only a guarantor of individual rights and as such does not determine individual ability or power; it occupies the second position whilst the first is taken up by personal rights or property.

Locke calls property or dominium the right of every man in the state of nature to dispose of himself and his possessions as he thinks fit; for him every man has a property in his own person, by which he means that a man has a natural right, limited only by God's purposes and by the obligation to respect the same right of others, to do as he pleases. He may not destroy himself because he is God's creature. His property in himself is not independent of God's will but is not connected with God's reason - as in Aquinas's doctrine. There is no eternal law whose norms are implemented to all created beings in the form of natural

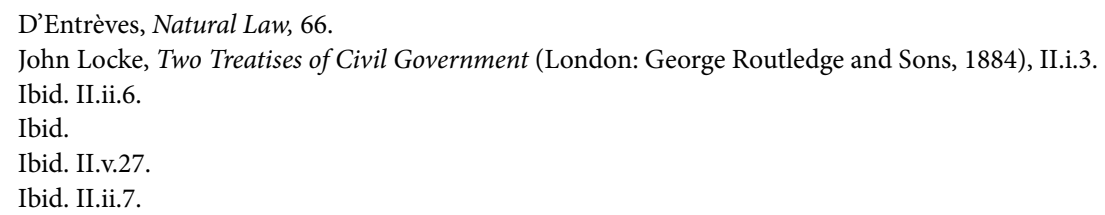


inclinations, with which all rational natural law norms are compatible. Rather, there is only one inclination, which directs the individual not to his supernatural and ultimate end but reduces him to the natural or material reality and is a foundation of his rights but not law. As a consequence, God alone guarantees not the essence of law as a set of norms, but the essence of rights as a personal ability/power. The state of nature is not a state of war, but not because every individual has a natural inclination to live in a political community, but because this state is quite different from the state of civil society. It is not a state of war because reason governs in it, pure reason, free from every passion and every prerational, even biological inclination, which knows the natural rights of every individual. The substance of it is very simple since reason or the law of nature knows only one norm: you may not invade the rights of others; if there are no rights, the law of reason will be quite empty.

But here Locke has an important problem: in the state of nature men had the law of nature to guide them but they, from time to time, must have differed about the law or about its application to particular cases. They must therefore have felt a need for an established, settled known law, received and allowed by common consent to be the standard of right and wrong, and also for a known and indifferent judge, with authority to determinate all differences according to the established law, and lastly for a power to back and support the sentence when right, and to give it due execution. ${ }^{34}$ By putting themselves under government, men do not give up all their rights, but only those which must be surrendered for the common good, which is only the preservation of freedom or property or a set of personal, passive rights. They give up only two active rights or powers: to interpret the norm of the law of nature and to punish. Government, which is like a society and not like a natural institution, has no absolute authority, but only as much as it needs for the common good which is defined now as a sum of individual interests and in no sense as the good of a whole community. The law of nature, this only one norm, stands - says Locke - an eternal rule to all men, legislators as well as others. ${ }^{35}$

The Two Treatises is the most radical answer that has been given yet to the main moral-jurisprudential $17^{\text {th }}$ century question of who has and who has not the 'right' to political power. For Locke, each individual does have and should have the political power in the juridical form of personal rights. Therefore, first, prior to and independent of the establishment of institutionalised forms of government, people are able to govern themselves; and, second, the power of institutionalised forms of government is derived from the original powers of the individual members of the political society. But, third, and most importantly, which in some sense connects Locke with Aquinas but makes him

\footnotetext{
Ibid. II.ix.124.

35 Ibid. II.xi.134. On the other hand, for Locke the same law of nature that does by this means give us property, does also bound that property too. 'God has given us all things richly' (I Tim. vi.17), is the voice of reason confirmed by inspiration. But how far has he given it us? To enjoy. As much as anyone can make use of to any advantage of life before it spoils; so much he may by his labour fix a property in. Whatever is beyond this, is more than his share, and belong to others (Ibid. II.v.31).
} 
quite different from the majority of modern natural freedom theorists, individuals have not only the right to defend themselves and their possessions from attack, even to kill the attacker if necessary, and not only this right of defence, but also political power, having it individually and not as a corporate body. By arguing in the Two Treatises that the state of nature has a law of nature enforced by the passive system Locke showed that natural freedom is not the Hobbesian 'absence of restraint' (or 'negative liberty') but - like in the doctrine of Aquinas - the juridical form of freedom as action within the boundaries of law and is subject to it. ${ }^{36}$ It stems from the constitutive role of the law of nature or law of reason that individuals who transgress it, in civil or natural society, by using 'Force without Right' or manifesting a 'declared design' to do so, place themselves outside moral human society, and thereby in a 'state of war'. ${ }^{37}$

Locke's innovation here - one may say ${ }^{38}$ - is to argue that the fundamental natural law (or law of nature) is not self-preservation but the 'preservation of mankind'. However, we must remember about the foundations of his law of nature which are quite different from Aquinas as a consequence of his individualistic and not communitarian premises, as well as his appeal to natural rights and not to natural inclinations on which the norms of natural law are grounded. If we do not remember Locke's individualistic premises, we may not understand his radical breaking with the Aristotelian-Thomistic tradition and make the same error as Tully, who has written that natural property rights are (in Locke's doctrine) use-rights within a larger framework of rights and duties to preserve the community (mankind) and regulated by everyone through the accusatory system. ${ }^{39}$ We may not be able to see that for this classic of reason in early liberalism, which is natural law, teaches all mankind who will but consult it, that [...] no one ought to harm another in his life, health, liberty, or possessions, namely in his personal and subjective rights, but only if his own selfpreservation is secured. We may also not be able to see the anti-naturalistic consequences of Locke's contractual conceptions of society and state, as well as his identifications of right or ius with power or dominium, 'objective' and 'subjective right' and the norma agendi and the facultas agendi, which are crucial for modern political philosophy, especially the liberal one.

\section{NATURAL LAW VS LAW OF NATURE}

As we have already observed, there is a clear tension between natural law and the law of nature: advocates of the former put emphasis on the realisation of inborn inclinations, view

\footnotetext{
$36 \quad$ Ibid. II.iv.22; II.vi.57. See James Tully, 'Locke on Liberty', in Conceptions of Liberty in Political Philosophy, ed. by Zbigniew Pelczynski and John Gray (New York: St Martin’s Press, 1984).

37 Locke, Two Treatises, II.iii.16, 19.

38 See, for example, James Tully, 'Locke', in The Cambridge History of Political Thought 1450-1700, John H Burns (Cambridge: Cambridge University Press, 1991), 627.

39 Ibid. 628.
} 
rights as manifestations of this realisation and natural law as a set of norms protecting the inclinations and indicating the limits of rightful actions. Advocates of the latter emphasise inborn rights of the subject whose execution may not be restrained either by other individuals, the state or Church. For proponents of natural law, state legislation is supposed to protect inclinations and respect the 'supreme law' they have been secured by in the first place. For proponents of the law of nature, state legislation is only supposed to interpret the inviolable status of the rights; the 'supreme law' can still be found there but only as a guarantor of the rights to live, stay healthy, move places and dispose of properties, not as a pathway to salvation. Individuals are then protected against the normative claims of both the state, Church and groups they belong to: at any time the individuals can separate from these 'entities' for the sake of their rights. Last but not least, while for the advocates of natural law family is a 'natural' group or even a sacramental union established to raise offspring, for advocates of the law of nature it is merely a dissoluble civil union based on mutual agreement.

As long as there were widespread mass parties that were supposed to reflect the interests of nations or 'social classes', so, let us say, until the 1950s, there was a tendency to picture individuals as parts of some bigger whole ('class', nation or even Church) and identify their particular natures with group particularities. Actually, it is only the slogans of the 'end of history' and global individualistic project of the 1990s that finally dissolved national and religious particularities. From that time on, individuality has clearly been prioritised and simplified liberal arguments have been used to picture all groups (apart from 'cultural groups') as critical points of reference and foundations for so-called populisms. The struggle of this simplified liberalism with populist projects can easily be called the sign of our times. Among the 'populisms', there is also the Catholic-based project with natural law as a critical counterpoint to the liberal understanding of inborn human rights.

Attempts by the Church to stay independent of political powers and exert influence on the political sphere only by means of citizens were contested in the $17^{\text {th }}$ and $18^{\text {th }}$ century first by regalism and then by democratic tendencies where the king was replaced by the people (or 'political nation'). Thanks to the doctrine of sovereignty, it is the people who then held exclusive rights to legislate and determine the limits of individual liberties, thus deciding on the content of law with no intermediate bodies like communities of believers. Erastian tendencies got involved in the theory of democracy with Jean-Jacques Rousseau who made the expression of 'general will' by the sovereign people into the only source of legal order and thereby sublated the Christian conflicts over loyalty either to God or to the emperor by the general will of free and equal individuals: free to legislate and equal in their legislative voice. Consequently, the sovereign people got more powerful than the Roman emperor. Rousseau's democratic doctrine justified - at least theoretically - both the dominance of state over Church and other communities subject to the 'general will', and the dominance of this will over 'private wills' of believers. All intermediate bodies, including the Church, threatened the identification of particular wills with the 'general will' and, as such, they could be abolished as an obstacle on the way to freedom. This freedom was also potentially threatened by family, which was contested by the followers of Rousseau 
as the institution mainly focused on particular interests of its members. Both parents and children were believed to realise their freedom only if and as long as they belonged to the people and served it, which made it justified for the people to legally impose methods of raising and educating a child. If we add to this that the family was only supposed to care for the productivity of bodies, not for future salvation, the path to biopolitics focused on the discipline of bodies was left wide open.

It is not this tendency, however, which has recently been given primacy, but the individualistic one. Unlike early modern individualism, it is not so much focused on defining the limits of state activity and establishing the untouchable private sphere but on guaranteeing individuals the execution of their rights - freed from the outdated restrictions of legal and moral nature. As a result, Churches have been made into associations of individuals professing the same religion. The so-called liberal separatism is increasingly calling for state neutrality with moral norms treated as particular normative propositions not binding for all the citizens. Admittedly, it is already philosophers of the Enlightenment who deprived the state of its religious functions and confined them solely to peacekeeping, but the peace could then be preserved by the Voltairian 'enlightened monarch'. Now the main actors are individuals whose choices determine the foundation of universally binding norms - usually based on the arithmetic majority principle. This tendency has also been understood by the Catholic Church which - beginning with the pontificate of Pope John XXIII - has abandoned the traditional primacy of truth over freedom in favour of the rights of a human person.

\section{CONTEMPORARY CATHOLIC POSITION}

We know that from the Christian (and among others also from Catholic) perspective, God (not only as Creator but also as Lord) transcends all creatures. Man, as His creation, is by nature and vocation a religious being. Coming from God, going toward God, man lives a fully human life only if he freely lives by his bond with God. ${ }^{40}$ Thanks to Him man knows the moral law, the work of divine Wisdom, which prescribes for man the ways, the rules of conduct that lead to the promised beatitude; it proscribes the ways of evil which turn him away from God and his love. It is at once firm in its precepts and, in its promises, worthy of love. ${ }^{41}$ It is moral law, not created in the 'political processes'; such moral law presupposes the rational order, established among creatures for their good and to serve their final end, by the power, wisdom, and goodness of the Creator. All law finds its first and ultimate truth in the eternal law. Law is declared and established by reason as a participation in the providence of the living God, Creator and Redeemer of all. ${ }^{42}$ It is also natural law, and not personal rights as natural rights, which participates in His providence; such moral natural law - as a set

\footnotetext{
Catechism of the Catholic Church, n. 44.

Ibid. n. 1950.

Ibid. n. 1951.
} 
of norms and not rights - expresses the original moral sense which enables man to discern by reason the good and the evil; they are written and engraved in the soul of each and every man, because it is human reason ordaining him to do good and forbidding him to sin. But this command of human reason - as said at the end of the $19^{\text {th }}$ century by the Roman Pope Leo XIII, often presented as a founder of the Catholic social teaching - would not have the force of law if it were not the voice and interpreter of a higher reason to which our spirit and our freedom must be submitted. ${ }^{43}$ These natural law norms are not only immutable and permanent, and hence independent of the variations of history and the various cultures, ideologies and religions, but also universal in [their] precepts and [their] authority extends to all men, not only to Christians but also to non-Christians, to atheists or agnostics as well as to the believers of other monotheistic religions. Natural law expresses the dignity of the person and determines the basis for his fundamental rights and duties. ${ }^{44}$ But if it expresses the dignity of the person and determines the basis for his fundamental rights and duties, at the same time it shows the negative borders for human actions, also for actions of every legislator. We must also know that natural law - once again: as a set of norms which every man and every member of the legislative bodies knows, should or could know - provides the indispensable moral foundation for building the human community. ${ }^{45}$

We know that the natural right theory in the Aristotelian or Aristotelian-Thomistic position, which is so important even for John Paul II in Veritatis Splendor, is connected with a teleological view of the universe: all natural beings - as Strauss put it - have a natural end, a natural destiny, which determines what kind of operation is good for them. In the case of man, reason is required for discerning these operations. Reason determines what is by nature right, with ultimate regard to man's natural end, and - we have to say - to man's natural inclinations which direct him to this end (as we saw in Aquinas's investigations). But this teleological view of the universe, of which the teleological view of man forms a part, has been destroyed for all practical purposes by modern natural science, also by liberals like Hobbes and Locke, whose mechanical conceptions situated every man only in relation to other individuals. From the point of view of Aristotle [...] the issue between the mechanical and teleological conception of the universe is decided by the manner in which the problem of the heavens and the heavenly bodies and their motion is settled. Now in this respect, which from Aristotle's own point of view was the decisive one, the issue seems to have been decided finally in favour of the mechanical conception of the universe. Here is the crucial point: the mechanical, or at any rate non-teleological conception of the universe, had to be accompanied by a non-teleological conception of human life. This 'naturalistic solution' proves to be impossible. It is impossible to banish ends from the social sciences, or what amounts to the same thing, to conceive of ends as derivative from desires or impulses. Therefore the alternative has prevailed: which means that we have had to accept a typically modern dualism of a nonteleological natural science and a teleological science of man. This is the position which the 
modern followers of Thomas Aquinas, among others, are forced to take, a position which implies a radical break with the thought of Aristotle, as well as that of Thomas Aquinas himself. The fundamental dilemma in whose grip we are, is the one caused by the success of modern natural science, a success which is presupposed rather than made doubtful by the so-called crisis in physics. An adequate solution to the problem of natural right cannot be found before this basic problem has been solved. ${ }^{46}$ But we should remember that Christian reflections are still connected with God; human dignity is universal because every man has God's provenience; his dignity is grounded on his nature which has a source in God and thanks to His will every man - as His creation - is a human person like Him. Still, from this perspective, every human person acts rightly when he goes to the end connected with God, to salvation. Such a right act has a moral value and ought to be secured by legal norms. Here we still have a teleological position and moral dimension of acts. In modern conceptions, first of all in liberal ones, the teleological perspective is beyond rational knowledge. Rights which were grounded in the Thomistic view have no foundation in rational, mechanical knowledge; or, in other words, natural rights are rejected first of all in the name of History, which (through anthropology) teaches us that no such right exists because instead of the supposed uniformity, we find an indefinite variety of notions of right or justice. But History is critical not only of the naturalistic essence of Thomistic rights, but also of the liberal, especially Lockean, set of universal rights. If we are still thinking of rights in terms of individual freedom or a sphere of privacy, if we are still thinking of rights as a negative area which is at the disposal of a specific individual only, we see them as to create subjective decisions by subjective conscience. Such conscience is not directed towards any supernatural end but only towards other individuals or a mechanically conceived society. When the existence of universal principles had to be denied, rights or law were radically separated from morality (the idea or the ideal of justice which sees natural rights directed to supernatural end) and substituted by natural rights of mechanical space.

In the Pastoral Constitution on the Church in the modern world "Gaudium et spes" of the Vatican Council II (1965), we still have a thesis that all political authority must be realised within the borders of the moral order ${ }^{47}$ and what is to be realised there is above all the inalienable right to life of every innocent human individual which is a constitutive element of a civil society and its legislation. ${ }^{48}$ This right is the human right and - at the same time - the right of every human person which is the foundation of human dignity and all other human rights. But all human persons as well as all human legislators ought to respect the moral order (connected - as we saw - with natural law) and make the right

\footnotetext{
Strauss, Six lectures, 7-9.

Gaudium et spes, n. 74 .

8 'The inalienable rights of the person must be recognized and respected by civil society and the political authority. These human rights depend neither on single individuals nor on parents; nor do they represent a concession made by society and the state; they belong to human nature and are inherent in the person by virtue of the creative act from which the person took his origin. Among such fundamental rights one should mention in this regard every human being's right to life and physical integrity from the moment of conception until death' (Catechism of the Catholic Church, n. 2273).
} 
of life of every (innocent) human individual compatible with it. For all human beings, interpersonal relationships are vital but for Christians they are constitutive, especially for the Christian vision of the human person as a being in relationship with God, with himself, with others and with nature: 'Being a person in the image and likeness of God [...] involves existing in a relationship, in relation to the other 'I' because God himself, one and triune, is the communion of the Father, of the Son and of the Holy Spirit', as we are reading in the Compendium of the Social Doctrine of the Church, ${ }^{49}$ and everything is related, everything is connected, as we are reading several times in Pope Francis's Encyclical Laudato Si'. The fact that every human person is a being in relationship not only with God and with himself, but also with others and with nature - which is also crucial for him and for these relationships - directs him towards his supernatural end and creates the fundamental moral context also for his legislation. As stated by the Vatican Council II, the correctness, justness and even legitimacy of the evanescent or temporal legal order depends on the realisation of the moral order ${ }^{50}$ and - as Pope John Paul II declared - the social organisation exists for supporting the rights of humans. ${ }^{51}$ From this perspective, the social organisation and its legal order exists not only for creating interpersonal peace but also for securing the fundamental rights of humans which are realised inside the natural law borders, being borders of the moral order prior to human will. As a consequence, the Catholic Church still presents this perspective on the rights of humans and natural law; still respects universal human inclinations as a foundation of natural law and - at the same time - human rights. Neither situationism, nor consequentialism and pure pragmatism could justify any attempt to negate the rules of natural law and - through it - the right of the human person. The Church now and again needs to show this position and the crucial point of the true foundation of the liberal-democratic societies also in in $21^{\text {st }}$ century; as Ernst-Wolfgang Böckenförde said in 2010: To conceive of such a state the liberal order needs a unifying ethos, a "sense of community" among those who live in this state. The question then becomes: what is creating this ethos, which can neither be enforced by the state nor compelled by a sovereign? One can say: first the common culture. But what are the elements and factors of that culture? Then indeed we are dealing with its sources such as Christianity, Enlightenment and humanism. But not automatically any religion. ${ }^{52}$

49 Pontifical Council for Justice and Peace, Compendium of the Social Doctrine of the Church, n. 34.

50 Gaudium et spes, n. 41, 59, 36. 'The citizen is obliged in conscience not to follow the directives of civil authorities when they are contrary to the demands of the moral order, to the fundamental rights of persons or the teachings of the Gospel. Refusing obedience to civil authorities, when their demands are contrary to those of an upright conscience, finds its justification in the distinction between serving God and serving the political community. "Render therefore to Caesar the things that are Caesar's, and to God the things that are God's." "We must obey God rather than men"' (Catechism of the Catholic Church, n. 2242).

51 John Paul II, 'Speech on Philippines', L'Osservatore Romano (Polish ed.) no 3 (1981).

52 "Freiheit ist ansteckend" Archived 2010.11.04 at the Wayback Machine, Frankfurter Rundschau, 1. November 2010 online, 2. November 2010, S. 32f. See also a very interesting discussion on this problem in German (positions e.g. Helmut Klages, Ronald Inglehart, Gerhard Himmelman, Jürgen Habermas, Elisabeth NoelleNeumann, Michael Haus and Axel Montenbruck). 
As we read in the Declaration on Religious Freedom "Dignitatis Humanae" on the right of the person and of communities to social and civil freedom in matters religious (1965): A sense of the dignity of the human person has been impressing itself more and more deeply on the consciousness of contemporary man, and the demand is increasingly made that men should act on their own judgment, enjoying and making use of a responsible freedom, not driven by coercion but motivated by a sense of duty. The demand is likewise made that constitutional limits should be set to the powers of government, in order that there may be no encroachment on the rightful freedom of the person and of associations. This demand for freedom in human society chiefly regards the quest for the values proper to the human spirit. It regards, in the first place, the free exercise of religion in society. This Vatican Council takes careful note of these desires in the minds of men. It proposes to declare them to be greatly in accord with truth and justice (n. 1). The Second Vatican Council and the latest popes still emphasised some inviolable rights of humans to life and to religious freedom as a ground for the constitutional order of society which has a foundation in the very dignity of humans; dignity which is known also by reason itself and not only by the revelation of God..$^{53}$

It is state institutions which have been made responsible for keeping this 'new deal'. Churches are allowed to teach and thanks to the freedom of religion individuals are allowed to follow the teachings in their lives but, as the state is supposed to be neutral, no Church teachings (no matter if based on revelation or reason) can any longer be given legal value. Although the Catholic Church keeps insisting on its exceptional teaching authority which should guide both citizens and rulers, it has now been recognised as merely one of multiple intermediate structures which shall be confined to the private, non-political sphere.

53 But a critical point for non-Catholics is rooted in a moral obligation to seek the truth by every man, who has the duty, and therefore the right, to seek the truth in matters religious in order that he may with prudence form for himself right and true judgments of conscience, under use of all suitable means (Dignitatis humanae, nos 2 and 3). We must remember that another crucial problem is connected with the theories of rights. As Raymond Plant wrote: It might be thought paradoxical to argue that theories of rights could help to fill the legitimation deficit of liberal societies, since a theory of rights surely has to have some kind of moral foundation, and yet precisely the problem with liberalism, according to its critics, is that we cannot have a cognitive moral theory (morality is seen as a matter of subjective preference) and we do not have a non-instrumental view of reason (reason cannot establish moral truths). Yet, frequently, theories of rights have been introduced as attempts to provide a basic moral framework to regulate the relationships between members of liberal societies who differ profoundly about morality. This strategy involves 'putting the right before the good', in Rawls' felicitous phrase. We disagree about the good, and we cannot accept that an authoritative view of the good can be established. Nevertheless, it is argued, it may be possible to reason about the right, that is to say about the framework of rights, which is appropriate and legitimate to regulate the relationships of those who differ fundamentally about the good. This, for example, is the position taken by the American philosopher Alan Gewirth, and is certainly one of the most subtle justifications of rights that recognises the fact of moral diversity and pluralism. At the same time, the whole rightsbased strategy has been criticised by Alasdair MacIntyre, who [...] is a major inspiration to narrative theology and very important for contemporary Catholics (Raymond Plant, Politics, Theology and History [Cambridge: Cambridge University Press, 2001], 225-226). 


\section{REFERENCES}

1. Aquinas, St. Thomas, Summa Theologiae, 1a 2ae, ed. by Thomas Gilby. London, 1966.

2. Aquinas, St. Thomas, On the Government of Rulers. De regimine principium, transl. by James M Blythe. Philadelphia: University of Pennsylvania Press, 1997.

3. Bourke, Vernon J, 'Is Thomas Aquinas a Natural Law Ethicist?' The Monist 58, no 1 (1974), 52-66. Online: https://doi.org/10.5840/monist19745814

4. Brown, Oscar J, Natural Rectitude and Divine Law in Aquinas. An Approach to an Integral Interpretation of the Thomistic Doctrine of Law. Toronto: Pontifical Institute of Mediaeval Studies, 1981.

5. Catechism of the Catholic Church, 1992. Online: www.vatican.va/archive/ENG0015/ INDEX.HTM (09.11.2021.)

6. Copleston, Frederick, A History of Philosophy. Ockham to Suarez. New York: Doubleday, vol. III, 1953.

7. Copleston, Frederick, Aquinas. Harmondsworth: Penguin Books, 1955.

8. Dignitatis humanae, 1965. Online: www.vatican.va/archive/hist_councils/ii_vatican_ council/documents/vat-ii_decl_19651207_dignitatis-humanae_en.html (09.11.2021.)

9. D'Entrèves, Alessandro Passerin, Natural Law. An Introduction to Legal Philosophy. London: Hutchinson University Library, 1957.

10. Figgis, John Neville, Studies of Political Thought from Gerson to Grotius. 14141625. Cambridge: Cambridge University Press, 1931.

11. Gaudium et spes, 1965. Online: www.vatican.va/archive/hist_councils/ii_vatican_ council/documents/vat-ii_const_19651207_gaudium-et-spes_en.html (09.11.2021.)

12. Gentilis, Albericus, Regales disputationes tres: id est, De potestate regis absoluta. De vnione regnorum Britanniæ. De vi ciuium in regem semper iniusta. London: [really Hanau] apud T. Vautrollerium, 1605.

13. Gilby, Thomas, Principality and Polity. Aquinas and the Rise of State Theory in the West. London: Longmans, Green, 1958.

14. Hobbes, Thomas, Leviathan. London: Dent, 1931.

15. John Paul II, 'Speech on Philippines'. L'Osservatore Romano (Polish ed.) no 3 (1981).

16. Jones, John Walter, Historical Introduction to the Theory of Law. Oxford: Clarendon Press, 1940.

17. Levy, Ernst, 'Natural Law in Roman Thought'. Studia et Documenta Historiae et Iuris 15, (1949), 1-23.

18. Locke, John, Two Treatises of Civil Government. London: George Routledge and Sons, 1884.

19. McGrade, Arthur Stephen, The Political Thought of William of Ockham. Personal and Institutional Principles, Cambridge: Cambridge University Press, 1974. Online: https://doi.org/10.1017/CBO9780511561238

20. McGrade, Arthur Stephen, 'Ockham and the Birth of Individual Rights', in Authority and Power. Studies in Medieval Law and Government presented to Walter Ullmann 
on his Seventieth Birthday, ed. by Brian Tierney and Patrick Linehan. Cambridge: Cambridge University Press, 1980, 149-165.

21. Monahan, Arthur P, From Personal Duties towards Personal Rights. Late Medieval and Early Modern Political Thought, 1300-1600. Montreal-Kingston: McGill-Queen's University Press, 1994.

22. Ockham, William, Opus Nonaginta Dierum, ed. by R F Bennett and J G Sikes. Manchester: Manchester University Press, 1940.

23. Plant, Raymond, Politics, Theology and History. Cambridge: Cambridge University Press, 2001.

24. Pontifical Council for Justice and Peace, Compendium of the Social Doctrine of the Church. Città del Vaticano: Libreria Editrice Vaticana, 2004.

25. Rommen, Heinrich, Die ewige Wiederkehr des Naturrechts. München: J. Kösel, 1947.

26. Runciman, David, Pluralism and the Personality of the State. Cambridge: Cambridge University Press, 1997. Online: https://doi.org/10.1017/CBO9780511582967

27. Strauss, Leo, The Political Philosophy of Hobbes. New York: The University of Chicago Press, 1936.

28. Strauss, Leo, Six lectures 1949. Online: https://press.uchicago.edu/sites/strauss/ natural_right/transcript_Strauss_six_lectures_1949.pdf

29. Szlachta, Bogdan, 'Nowożytny przełom w pojmowaniu prawa naturalnego', in Kształtowanie postawy obywatelskiej, ed. by P. Lenartowicz. Kraków: Wydawnictwo WAM, 1997, 35-80.

30. Tierney, Brian, Religion, Law, and the Growth of Constitutional Thought 11501650. Cambridge: Cambridge University Press, 1982. Online: https://doi.org/10.1017/ CBO9780511558627

31. Tuck, Richard, Natural Rights Theories. Their Origin and Development. Cambridge: Cambridge University Press, 1979. Online: https://doi.org/10.1017/CBO9781139163569

32. Tully, James, 'Locke on Liberty', in Conceptions of Liberty in Political Philosophy, ed. by Zbigniew Pelczynski and John Gray. New York: St Martin’s Press, 1984.

33. Tully, James, 'Locke', in The Cambridge History of Political Thought 1450-1700, ed. by John H Burns. Cambridge: Cambridge University Press, 1991, 616-652. Online: https://doi.org/10.1017/CHOL9780521247160.023

34. Villey, Michel, 'La Genèse du droit subjectif chez Guillaume d'Occam'. Archives de Philosophie du Droit, 9, (1964), 97-127. 
Bogdan Szlachta is Full Professor of Humanities, lawyer and philosopher, Head of the Chair of Political Philosophy at the Jagiellonian University in Krakow and Chair of Theory and Philosophy of Politics at the Academy Ignatianum in Krakow. Editorin-Chief of the academic journals: Politeja. The Journal of the Faculty of International and Political Studies JU and Myśl Polityczna. Political Thought. Author of several monographs (e.g. $Z$ dziejów polskiego konserwatyzmu [From the History of Polish Conservatism], Kraków, 2000 and Monarchia prawa? Angielska myśl polityczna doby Tudorów [A Monarchy of Law? English Political Thought at the time of the Tudors], Kraków, 2008), collections of essays, many academic articles and encyclopedia entries; editor of collections of articles (e.g. Słownik społeczny, Kraków 2004) as well as of source texts (e.g. Biblioteka Klasyki Polskiej Myśli Politycznej [The Library of Classics of Polish Political Thought] Series). Member of the London-based Academia Europaea. Research interests: history of Western, especially liberal and conservative, political thought, Christian and contemporary political philosophy. 